\title{
Financialization and financial profit
}

\section{ARTURO GUILLÉN*}

This article starts from the critical review of the concept of financial capital. I consider it is necessary not to confuse this category with of financialization, which has acquired a certificate of naturalization from the rise of neoliberalism. Although financial monopoly-financial capital is the hegemonic segment of the bourgeoisie in the major capitalist countries, their dominance does not imply, a fortiori, financialization of economic activity, since it depends of the conditions of the process reproduction of capital. The emergence of joint stock companies modified the formation of the average rate of profit. The "promoter profit" becomes one of the main forms of income of monopoly-financial capital. It is postulated that financial profit is a kind of "extraordinary surplus-value" which is appropriated by monopoly-financial capital by means of the monopolistic control it exerts on the issue and circulation of fictitious capital.

Keywords: financial capital; financialisation; financial profit; Hilferding-promoter's profit.

JEL Classification: E44.

And as soon as formation of capital were to fall into the hands of a few established big capitals, for which the mass of profit compensates for the falling rate of profit, the vital flame of production would be altogether extinguished. It would die out.

- Karl Marx, Capital

\footnotetext{
* Research Professor of Economics and Coordinator of the Social Economy Branch of the Graduate Program in Social Studies, Universidad Autónoma Metropolitana, Iztapalapa, Mexico City. General Coordinator of the Celso Furtado European/Latin American Network for Development Studies (www. redcelsofurtado.edu.mx). Academic Chair of the PROMEP Financial Globalization and Sustainable Development Network. Member of the Mexican National System of Researchers. E-mail: artguillenrom@ hotmail.com. Submitted: 5/August/2013; Approved: 28/October/2013.
} 


\section{INTRODUCTION}

The global crisis is about to enter its sixth year. Although there is an abundance of literature analyzing its nature from different theoretical perspectives, much work remains to be done in order to understand its structural causes. In this article I will explore various aspects of the problem in an attempt to move the analysis forward.

In my opinion, the current economic-financial crisis requires a return to a debate at the heart of Marxism that took place at the end of the nineteenth century and beginning of the twentieth: a debate about the category of financial capital. A renewed discussion of this category, beginning with the pioneering analysis of Rudolf Hilferding, is a necessary step toward comprehension of the dynamics and financialization of contemporary capitalism. Finance capital is the dominant form of capital in the monopolist or imperialist stage of capitalism. Sweezy (1994) suggested replacing the concept of finance capital with that of monopoly-finance capital, a term that better describes the nature of such capital, and which I will therefore use here.

As a social relation, monopoly-finance capital is subject to change and recomposition in its process of development. Its modes of operation, on the other hand, are subject to the concrete conditions of capital reproduction. For this reason there are periods in which productive investment tends to predominate over financial or speculative operations, whereas in other stages, like the one holding sway since the 1980 s, the economy is "financialized," and the financial sphere imposes its operational logic on the accumulation of capital. This is why monopoly-finance capital and financialization are distinct, though interconnected, categories.

Second section of this article develops the definition monopoly-finance capital in its historical context. Third section analyzes the process of financialization. Following Braudel (1992) and Arrighi (2004), it is postulated that financializations are not recent phenomena of contemporary history, but have historically been linked to periods of hegemonic transition, where the hegemonic power of the moment attempts to use its monetary and financial domination to preserve its position. Such is the case today with the United States, the driving force behind contemporary financialization. I emphasize that this means not simply a quantitative phenomenon relative to the predominance of the financial over the productive, but also a qualitative transformation, a new finance-dominated accumulation regime, as proposed by Chesnais (1994). Fourth section focuses on the determinants of financial profit formation and the behavior of the average rate of profit, with special emphasis on the importance of "promoter's profit." Conclusions are presented in fifth section.

\section{THE CONCEPT OF MONOPOLY-FINANCE CAPITAL}

The global economic-financial crisis requires a return to the debate over the category of finance capital. For Marx, money capital is remunerated based on the rate of interest. It is a form of capital with the cycle $\mathrm{M}-\mathrm{M}$ ', which appropriates 
a part of social surplus value without passing through production. It was the miracle of money breeding money: in Marx's words, the miracle of the pear tree producing pears ${ }^{1}$. During the free competition phase of capitalism in which Marx wrote, social capital was divided among clearly differentiated fractions of the bourgeoisie: the industrial bourgeoisie, the banking bourgeoisie, and the commercial bourgeoisie. This division involved a sharp distinction among industrial profit, financial profit, and commercial profit. In the monopoly phase, however, the divisions among the distinct segments that make up the dominant class and those among the different forms of profit are no longer so clear. Toward the end of the nineteenth century, the process of concentration and centralization of capital in the major capitalist countries led not only to the formation of oligopolies and large joint-stock companies, but to a growing interconnectedness of capital and the proliferation of what Marx called fictitious capital.

The profound structural changes taking place with the rise of monopoly capital provoked an intense debate, in which Rudolf Hilferding, Lenin, and Bukharin figured most prominently. Unfortunately, the debate digressed into a discussion of whether the category of financial capital implied the control of banks over industry, or whether it meant something else. Such discussion about the possible control of banks, while a theoretically as well as politically important attempt to define the principal enemy of the working class, arose from an inadequate understanding of Hilferding's concept, as I will try to show below. And to a certain extent, that distorted interpretation followed from certain unfortunate statements of Hilferding himself.

Rudolf Hilferding (1877-1941) was one of the most important Marxist theorists of the early nineteenth century, along with Lenin, Bukharin, and Rosa Luxemburg, and the most astute student of finance economics among that group: the Marxist theorist of finance par excellence! The productivist slant in Marxism (the correct, but partial and insufficient appreciation of Marx as the theorist of production), coupled with the identification of Hilferding after the Bolshevik Revolution as a reformist and opportunist, relegated his work to the background of "official Marxism." However, more than a hundred years after the publication of his milestone work, Finance Capital (1910), a reassessment of Hilferding's contributions to the understanding of the capitalism of his time turns out to be essential, in spite of certain errors ${ }^{2}$, for the understanding of contemporary events. For those of us in political economy who conceive of "the present as history," his study of finance capital as a basic category of monopoly capitalism is of primary importance in

\footnotetext{
1 “[...] the category of interest - impossible without determining the rate of interest--is alien to the movements of industrial capital as such" (Marx, n.d., Ch. 23).

${ }^{2}$ Among others, these errors include the lack of a general theory of currency (S. De Brunhoff, 1973), the consideration of the monopoly price as more a subjective than an objective element determined by the law of value (Guillén, 1981), and the misjudgment in his final years that the development of finance capital led to the formation of a more stable "organized capitalism" in which the general crises of overproduction would be overcome. On critiques of Hilferding, see M. Pierre (2010).
} 
understanding the process of financialization and the recurring crises that have accompanied it since the 1980s.

Hilferding's most well-known definition of the category of finance capital is found in Chapter 14 of Finance Capital. In that chapter, entitled "The Capitalist Monopolies and the Banks: The Transformation of Capital into Finance Capital," he defines finance capital as follows:

The dependence of industry on the banks is therefore a consequence of property relationships. An ever-increasing part of the capital of industry does not belong to the industrialists who use it. They are able to dispose over capital only through the banks, which represent the owners. On the other side, the banks have to invest an ever-increasing part of their capital in industry and in this way they become to a greater and greater extent industrial capitalists. I call bank capital, that is, capital in money form which is actually transformed in this way into industrial capital, finance capital. (Hilferding, 1910, Ch. 14)

This first definition, in which Hilferding alludes principally to the role of credit in the process of expansion of large enterprises that organized themselves as jointstock companies, has occasioned diverse criticisms. It accepts that finance capital means, as Hilferding himself suggests, the domination of industry by banks. Lenin and Bukharin, for example, emphasized that it was not the domination of banking capital over industrial capital that was important - though they accepted the idea in general terms - but rather the "fusion" of both types of capital, which gives rise to the emergence of the financial oligarchy ${ }^{3}$. Paul Sweezy (1942, p. 260) argues that Hilferding "erred in the direction of overestimating the importance of financial dominance in the latest stage of capitalist development." In his opinion "the dominance of bank capital is a passing phase of capitalist development, which roughly coincides with the transition from competitive to monopoly capitalism" (Ibid., p. 268). Sweezy also maintains, with a certain justification, that the domination of industry by banks was a phenomenon more characteristic of the German development model than that of the U.S. He is also correct in saying, as he did with Paul Baran in Monopoly Capital (1966) that postwar capitalism in the U.S. depended mainly on financing with firms' own resources, more than on access to financial markets.

It seems to me, however, that the debate about the "domination" of banks is

\footnotetext{
${ }^{3}$ Referring to Hilferding's definition cited above, Lenin observes: "This definition is incomplete insofar as it is silent on one extremely important fact - on the increase of concentration of production and of capital to such an extent that concentration is leading, and has led, to monopoly. The concentration of production; the monopolies arising therefrom; the merging or coalescence of the banks with industry - such is the history of the rise of finance capital and such is the content of that concept.[...] Thus the beginning of the twentieth century marks the turning-point, not only in the growth of monopolies (cartels, syndicates, trusts), of which we have already spoken, but also in the growth of finance capital" (Lenin, 1963, Ch. 3, italics mine).
} 
deceptive and obscures what is crucial about Hilferding's contribution. I will try to demonstrate that Hilferding gave a more profound meaning to the category of finance capital. In the paragraph following his much-cited but careless initial definition, Hilferding writes:

Finance capital develops with the development of the joint-stock company and reaches its peak with the monopolization of industry... But the bank disposes of bank capital, and the owners of the majority of the shares in the bank dominate the bank. It is clear that with the increasing concentration of property, the owners of the fictitious capital which gives power over the banks, and the owners of the capital which gives power over industry, become increasingly the same people. As we have seen, this is all the more so as the large banks increasingly acquire the power to dispose over fictitious capital. (Hilferding, 1910, Ch. 14, italics mine)

This new approach to the concept puts at least two key points into relief: first, that finance capital is the result of the process of concentration and centralization of capital, as well as the emergence of the joint-stock company; and second, that the appearance of these companies not only implies the separation of ownership and control - which modifies the forms of management of the business - but also, perhaps more importantly, the control of finance capital over the issuance and circulation of fictitious capital, that is, capital in the form of stocks, bonds, and other types of securities. As Hilferding recognizes, that control of fictitious capital belongs not only to banks but also to big corporations linked to industry.

Fictitious capital, as Marx brilliantly saw, is a duplicate of the real capital invested in production. It is, to use a more contemporary metaphor, the hologram of productive capital. The proliferation of fictitious capital provokes, among other things, the development of stock and capital markets as privileged spaces for its movement.

For Marx, bonds representing public and private debts, as well as stocks, were fictitious capital, that is, a title to future surplus value. In his words:

Even when the promissory note - the security — does not represent a purely fictitious capital, as it does in the case of state debts, the capital-value of such paper is nevertheless wholly illusory... The stocks of railways, mines, navigation companies, and the like, represent actual capital, namely, the capital invested and functioning in such enterprises, or the amount of money advanced by the stockholders for the purpose of being used as capital in such enterprises... But this capital does not exist twice, once as the capital-value of titles of ownership (stocks) on the one hand and on the other hand as the actual capital invested, or to be invested, in those enterprises. It exists only in the latter form, and a share of stock is merely a title of ownership to a corresponding portion of the surplus-value to be realized by it. (Marx, n.d.:, Ch. 29) 
For Hilferding as for Marx, the fictitious character of capital is most clearly revealed in government bonds:

State bonds need not in any way represent existing capital. The money lent by the state's creditors could long ago have gone up in smoke. State bonds are nothing but the price of a share in the annual tax yield, which is the product of a quite different capital than that which was, in its time, expended unproductively. (Hilferding, 1910, Ch. 7)

Thorstein Veblen, who was an assiduous student of the rise of monopoly capital, and who believed that a "credit economy" had taken the place of a "monetary economy," agreed with Marx and Hilferding about the fictitious character of the capital represented by financial assets. For Veblen:

Loans obtained on property which has no present industrial use, which cannot in its present form or under existing circumstances be employed in the processes of industry (as, e.g., speculative real estate), or loans on property which is already engaged in the industrial process (as, e.g., stocks, industrial plant, goods on hand, real estate in use), represent, for the purpose in hand, nothing more substantial than a fictitious duplication of material items that cannot be drawn into the industrial process... To a very considerable extent the funds involved in these loans, therefore, have only a pecuniary (business) existence, not a material (industrial) one; and, so far as that is true, they represent, in the aggregate, only fictitious industrial equipment. (Veblen, 1904, Ch. 5)

Many years before Keynes ${ }^{4}$, Marx understood that the market in financial assets is relatively independent of the market in goods. The value of stocks and financial assets represents a legal title to future surplus value in the form of financial profit. Their value does not necessarily correspond to the value of real capital. The two may diverge, and in fact financial assets normally diverge during booms above the value of productive capital. Occasionally, however, as in crises, they diverge at a lower value. The market in financial assets is, for this reason, eminently speculative and obeys a different logic than that of productive capital. Hilferding understood this point well. In his words:

The price of a share is not determined as an aliquot part of the total capital invested in the enterprise and therefore a relatively fixed sum, but only by the yield capitalized at the current rate of interest. Since the

\footnotetext{
${ }^{4}$ For Keynes, the capital goods market is distinct from the market in financial assets. The price of real assets is based on the investment rate, which in turn depends on the effective utilities of companies and expectations of profit. The financial asset market, on the other hand, is purely speculative; it is a wager on the current price of an asset versus its expected price (Keynes, 1995).
} 
share is not a claim to a part of the capital in active use in the enterprise, its price does not depend upon the value, or price, of the industrial capital which is actually being used. It is a claim to a part of the profit, and therefore its price depends, first, on the volume of profit [...] and second, on the prevailing rate of interest... The share, then, may be defined as a title to income, a creditor's claim upon future production, or claim upon profit. Since the profit is capitalized, and the capitalized sum constitutes the price of the share, the price of the share seems to contain a second capital. But this is an illusion. What really exist is the industrial capital and its profit. (Hilferding, 1910, Ch. 7)

In the words of Marx:

The independent movement of the value of these titles of ownership, not only of government bonds but also of stocks, adds weight to the illusion that they constitute real capital alongside of the capital or claim to which they may have title. For they become commodities, whose price has its own characteristic movements and is established in its own way. Their market-value is determined differently from their nominal value, without any change in the value (even though the expansion may change) of the actual capital... All this paper actually represents nothing more than accumulated claims, or legal titles, to future production whose money or capital value represents either no capital at all, as in the case of state debts, or is regulated independently of the value of real capital which it represents. (Marx, n.d., Ch. 29).

To repeat, for Hilferding the defining power of the new oligarchy that emerged with the birth of finance capital was its control of fictitious capital. In Chapter 14, he reaffirms this idea:

The power of the banks increases and they become founders and eventually rulers of industry, whose profits they seize for themselves as finance capital, just as formerly the old usurer seized, in the form of "interest," the produce of the peasants and the ground rent of the lord of the manor. The Hegelians spoke of the negation of the negation: bank capital was the negation of usurer's capital and is itself negated by finance capital. The latter is the synthesis of usurer's and bank capital, and it appropriates to itself the fruits of social production at an infinitely higher stage of economic development. (Hilferding, 1910, Ch. 14)

In other words, finance capital is a new segment of capital - its dominant form in the era of monopolies and joint-stock companies - and not the old form of banking capital in the service of industry. It is neither the old banking capital in service of industry, nor the banking capital that dominates industry. What emerges from this fusion of banking and industrial capital, as Hilferding, Bukharin and 
Lenin well understood, is a new fraction of the bourgeoisie: the financial oligarchy that exercises hegemony over economic and political power, which not only dominates the operations of banking and finance, but also determines the modus operandi of the entire economy. As Hilferding rightly indicated in the introduction to his book, although finance capital means "an ever more intimate relationship" between banking and industrial capital, what is central to the concept is that "through this relationship [...] capital assumes the form of finance capital, its supreme and most abstract expression" (Hilferding, 1910, Preface). A similar interpretation of the concept of financial capital is offered by Dumenil and Levy, who define it as "the upper fraction of the capitalist class and the financial institutions and agents incarnations of his power (Dumenil \& Levy, 2006, p. 1).

\section{FINANCIALIZATION: A NEW ACCUMULATION REGIME}

The power of monopoly-finance capital should not be confused with the concept of "financialization" that gained currency in the last two decades of the twentieth century and the beginning of the twenty-first. Monopoly-finance capital has been the dominant part of capital since the transition to the monopoly or imperialist phase of capitalism. However, there have been periods of capitalist development in which the economy was not "financialized," such as the period 1950-70, in which there was a greater proportionality between the development of the productive and the financial spheres. In this period finance was kept under regulation and international movements of private portfolio capital were restricted. This situation began to change with the great crisis of the 1970 s, which can be characterized as a crisis in the mode of regulation in effect since the postwar period as well as in the Fordist accumulation regime by which it was sustained. The efficient cause of this crisis was the fall in the rate of profit in the major developed capitalist countries.

I have argued elsewhere (Guillén, 2007) that the reaction to that crisis of capital and its dominant element of monopoly-finance capital was to counteract the fall in the rate of profit by means of neoliberalism, a generic concept that brings together various related processes: a generalized offensive of capital against labor and the welfare state; an economic and trade globalization that entails liberalization of exchange and promotion of free trade agreements; the deregulation of goods and finance markets; financial globalization; and the financialization of the economy.

Financialization is not a new phenomenon in the history of capitalism. Braudel and Arrighi associate it with periods of maturing and decline of the hegemonic powers. For Braudel, the Mediterranean city-states (Geneva, Venice etc.) as well as Amsterdam and England in their time, experienced processes of financialization during the twilight of their hegemonic domination. He asks himself:

Was this burst of financial activity an aberration as some historians, taking a moral tone, have suggested? Was it not rather a moral development? [...] At all events, every capitalist development of this order see- 
ms, by reaching the stage of financial expansion, to have in some sense announced its maturity: it was a sign of autumn. (Braudel, 1984, p. 246)

If Braudel's thesis is correct, it would be consistent with the idea that modernday "financialization" is framed within the declining hegemony of the United States, which coincides precisely with the "Great Crisis of the 1970s." If this is true of current financialization, together with the other restructuration processes cited above, it would not only be an objective reaction to the profitability of the 1960s, but also a project of U.S. monopoly-finance capital and the State to contain its decline through the use of its financial and monetary hegemony. As Arrighi notes, the profitability crisis that initiated the crisis of the 1970s was "an aspect of a greater crisis of hegemony." According to him, financialization is "the predominant capitalist response to the joint crisis of profitability and hegemony" (Arrighi, 2007, p. 161). He concludes, taking up an idea of Calleo, that the hegemonic powers do not lose their position solely because new powers appear that threaten their leadership, but rather because instead of adapting to the new situation, they allow their hegemonic domination to lapse into methods of plunder.

Contemporary financialization is the offspring of the crisis of the 1970s. There is a close relation between financialization and the semi-stagnation that initiated that crisis. As Sweezy argues:

Traditionally financial expansion has gone hand-in-hand with prosperity in the real economy. Is it really possible that this is no longer true, that now in the late twentieth century the opposite is more nearly the case: in other words, that now financial expansion feeds not on a healthy real economy but on a stagnant one? The answer to this question, I think, is yes it is possible, and it has been happening. And I will add that I am quite convinced that the inverted relation between the financial and the real is the key to understanding the new trends in the world. (Sweezy, 1994, p. 5)

But there remains the question: What is financialization? What do we understand by this term? Various definitions have been offered. For Epstein (2005, p. 3), "financialization means the increasing role of financial motives, financial markets, financial actors and financial institutions in the operation of the domestic and international economies." Palley $(2007$, p. 1$)$ defines it similarly but in greater detail as "a process whereby financial markets, financial institutions and financial elites gain greater influence over economic policy and economic outcomes. Financialization transforms the functioning of economic system at both the macro and micro levels. Its principal impacts are to (1) elevate the significance of the financial sector relative to the real sector; (2) transfer income from the real sector to the financial sector; and (3) increase income inequality and contribute to wage stagnation. Additionally, there are reasons to believe that financialization may render the economy prone to risk of debt-deflation and prolonged recession." 
These definitions are a good description of financialization, but they leave the impression that it is just about quantitative change: the greater weight of the financial relative to the "real." They are also imprecise in confusing "the financial" with the "financial sector" and "financial institutions," when in reality financialization encompasses all the sectors of capital that carry out productive activities. For this reason we cannot view the "real sector" against the "financial sector," as Palley does, as if they were two separate and opposing domains.

It seems to me more fruitful to consider contemporary financialization as a qualitative change in the accumulation regime and to link this change with the process of profit accumulation - of financial profit, in particular - in conditions of crisis and under the domination of monopoly-finance capital. It would be more appropriate to definite financialization as $\operatorname{Kripnner}(2005$, p. 2) does: "a pattern of accumulation in which profits accrue primarily through financial channels rather than through trade and commodity production." Since the 1980s, we have seen the formation of what Chesnais (1994) termed the new "finance-dominated accumulation regime" (FDAR). This regime permits monopoly-finance capital to acquire large profits, but at the cost of increasing the volatility and fragility of "internal" financial systems and of the international monetary and financial system.

The FDAR means a qualitative change in the logic of capital accumulation. In this regime, the financial sphere to a great extent predetermines the productive sphere, subordinating it to its necessities: it is the priorities of monopoly-finance capital--that is, capital placed in financial markets for speculative ends - and not those of productive capital that order and determine the overall movement of capital accumulation. The management forms of large businesses and economic groups are modified, their function subjected to the needs of short-term profit. Firms are financialized. What matters now is the stock value of the corporation. The giant corporation oriented toward long-term profit and administered by what John Kenneth Galbraith (1972) called a "technostructure," that acted independently of stockholders, has experienced a thoroughgoing change. Although transnational corporations continue to be governed by technostructures, they now serve the interests of the stockholders, which means increasing the market value of the corporation, participating in the market through repurchase of shares to achieve this goal, entering the mergers and acquisitions game, and increasing profitability through active participation in financial markets. The income of managers depends increasingly on the value of their stock options.

The judgment of institutional investors in financial markets become the principal barometer of corporate behavior. Their growing weight in the share and management structure of corporations means that corporate decision-making responds more to short-term financial interests than to the long-term interests of production. Managers are answerable to shareholders. As Girard (2001, p. 313) notes, corporate governance "is transformed from a mechanism of a posteriori sanctions to one of a priori restrictions and regulations that fundamentally alters the goals and management methods of businesses."

The process of corporate mergers and acquisitions has been associated with the 
financialization of the economy. Although much is said of synergies and competitiveness as factors that drive mergers, the decisive factor is not so much the productive or commercial potential of the companies merged as the effect of the merger on stock values.

Financialization also entails the internalization of finance at the level of corporate groups. It implies, in the words of Chesnais (1994), "the creation of an internal financial market at the heart of corporate groups." The financial activities centralized in transnational corporations are oriented toward active operation of financial markets. Many corporations even create independent financial companies and carry out credit operations. Finance, as Passet (2000, p. 110) argues, is not only extended, but also "horizontalized." That is, "its nature changes — from a sector that is important but specific, it becomes one that permeates the economy, that is at the heart of all economic activity."

There has also been a profound transformation in the operations of financial systems. Commercial banks, under pressure from growing competition and the inflation of the 1970s, have lost ground to other financial intermediaries. In a context of rising interest rates, commercial banks found themselves confronted with disintermediation. There was a consequent securitization of the financial system, where investment banks, generally linked to large commercial banks, and nonbanking financial intermediaries, played a growing role. The banks became securitized: they began to issue their own securities in the bond markets. At the same time, they sought new sources of income in commissions, acting, for example, as intermediaries in the issuance of government bonds and of corporate bonds in international capital markets, as directors of international mergers and acquisitions, and through active participation in currency markets.

This is how the economy was globalized and financialized in the 1980s and 1990s. As already described, this finance-dominated accumulation regime subordinates the entire logic of capital accumulation to the appreciation of financial capital. At the peak of the financial pyramid are the transnational corporations, the large banks, the investment banks, the insurance companies, the operators of investment and pension funds, and the cream of the crop of large financial capital funds, which manage the resources of the richest men on the planet: hedge funds and private equity funds. Complex financial structures current predominate in the majority of countries; although there are important national differences, these generally consist of traditional deposit and credit activities together with financial intermediation and financing through bond markets, each serving different purposes. The increasing complexity of the financial structure corresponds to a process of constant innovation and diversification of financial instruments, to which derivatives have been added. Although commercial banks have lost penetration in traditional deposit and credit markets, they participate in and control the major financial markets. It would thus be a grave error to confuse banking disintermediation with a loss of importance of banks in the new financial structure.

The FDAR and the changes it has provoked in corporate management structures is, along with deregulation, the fundamental cause of the financial scandals and 
accounting frauds that have surrounded many corporations and financial institutions since the start of the new millennium. The new regime prompted executives to stretch profits to the extreme and become overindebted without taking into account the actual state of the companies or of the economy. It was an invitation to accounting fraud and the complacence and complicity of the auditors and rating agencies intimately involved with the same interests they supposedly monitored. But the causes of great crises are not frauds, though it must be recognized that perhaps never in the history of capitalism has the level of fraudulent operations reached such a high level as it has today, a fact which not only demonstrates the presence of a savage neoliberalism, but also a high degree of decomposition of capitalism. In this context it is worth recalling Fisher's comment on the depression of the 1930s:

At least one book has been written to prove that crises are due to frauds of clever promoters. But probably these frauds could never have become so great without the original starters of real opportunities to invest lucratively. There is probably always a very real basis for the "new era" psychology before it runs away with its victims... Thus over-investment and over-speculation are often important; but they would have far less serious results were they not conducted with borrowed money. That is, over-indebtedness may lend importance to over-investment or to over-speculation. (Fisher, 1933, pp. 349, 341)

For Fisher, the "dominant factors of great crises are over-indebtedness to start with and deflation following soon after" (Fisher, 1933, p. 341).

The process Fisher describes was repeated with the current global crisis, whose efficient cause was over-indebtedness. As several authors have already claimed, it was a debt-deflation crisis. But as will be argued below, behind this efficient cause there was a mechanism of profit accumulation favorable to the interests of the dominant monopoly-finance capital, which found in financialization a key method for increasing its share of social surplus value.

\section{THE RATE OF INTEREST, THE RATE OF PROFIT, AND FINANCIAL PROFIT}

For Marx, interest was the part of surplus value that the industrial capitalist ceded to the owner of money capital. In contrast to wages and profits, interest did not have a "natural" rate, but depended on the competition between borrowers and lenders. It was a distribution of surplus value compatible with the free competition phase in which, as already stated, there was a clear separation among industrial, commercial, and banking capital. In the monopoly phase of capitalism the forms of distribution of surplus value among the different fractions of the bourgeoisie, and between the bourgeoisie and the dominant financial oligarchy, are 
transformed. The financial oligarchy appropriates social surplus value, in large part by means of new financial mechanisms not previously in the hands of the distinct segments of capital.

Hilferding contributes important particulars concerning the new forms of surplus value appropriation under the domination of financial capital. In Chapter 7 of his book Finance Capital, in his examination of the emergence of joint-stock companies as a form of business organization, Hilferding makes a series of theoretical observations about the changes that prompt the development of fictitious capital in the distribution of social surplus value. In his view, the buyer of a stock receives, not the interest paid in a bank loan to the owner of capital, but a dividend that approximates the interest rate from the bank:

The rate of interest paid on money capital which is provided in the form of shares is not fixed in advance; it is only a claim on the yield (profit) of an enterprise. A second difference as against loan capital is that the return of capital to the money capitalists is not guaranteed. Neither the contract which defines their relationship to the enterprise, nor the relationship itself, gives them any such assurance... (Hilferding, 1910, Ch. 7)

The owner of the shares no longer has a right over the capital the stock represents, "only a claim to his proportionate share of the total return" (Ibid.). In other words, the dividend is neither the average profit of industrial capital, nor the interest rate on a loan or a fixed-income security, but a form of income that tends to approximate the rate of interest (given that this interest is the lower limit of capital remuneration), but which has an arbitrary value: it must be agreed upon by the boards of directors of the joint-stock companies. The majority of shareholders, who are not part of the financial oligarchy, must settle for a dividend that is less than the rate of profit and that approximates the rate of interest.

The reduction of dividends to a level close to the interest rate postulated by Hilferding, is not already present in the financially dominated accumulation regime (FDAR) prevailing in most capitalist countries since the eighties of the last century. Under this regime, aimed at maximizing shareholder value of corporations, the dividend becomes an important mechanism to remunerate shareholders, institutional funds and financial intermediaries that handle stocks within their portfolios (Baragar, F. \& Chernomas, R., 2012). In 1990-1998, dividends accounted for 49.6\% of corporate profits. Increased corporate shareholder value is achieved largely through a policy of buying back its own stocks. In the United States stock buybacks in 1980 accounted for $5 \%$ of corporate profits while in the nineties reached levels of over 20\% (Lazonick, W. \& O'Sullivan, M., 2000, pp. 7-8).

One of the most revolutionary aspects of Hilferding's theory is the category he labels the "promoter's profit" - the profit appropriated by finance capital for the mere act of negotiating the fictitious capital, that is, for controlling the issuance and circulation of stocks and public and private bonds and securities. Even considering all the differences between the current situation and Hilferding's time, it is 
this promoter's profit that plays a crucial role in present-day capitalism, and that was fundamental, for example, in the process of securitization and the creation of derivatives that accompanied the real estate boom of 1990-2007, and which led to the current global crisis.

The finance-dominated accumulation regime has governed capitalism since the 1980s; in it, according to Serfati (2010), "the lines between financial and non-financial activities are blurred," beginning with transnational companies. This regime rests on the promoter's profit as its main source of profit of monopoly-finance capital. Commercial banks, insurance companies, and large institutional investment funds, as well as transnational companies that operate in the productive sector, have access to promoter's profits. To visualize the current importance of the promoter's profit, we can note that in 2009 , financial companies received $42 \%$ of their income from fees and $58 \%$ from interest, as opposed to $20 \%$ and $80 \%$, respectively, in 1980 (Foster \& Magdoff, 2009, p. 55).

As Hilferding well understood, with the emergence of finance capital, the majority of shareholders had to content themselves with receiving a dividend approximately equal to the prevailing rate of interest, while a handful of big capitalists, those who had access to the initial offerings of fictitious capital, managed to reap large returns in the form of "promoter's profits." In Hilferding's words, the effect was to produce "the progressive reduction of dividends to the level of interest, while an ever increasing share of the total profits of the enterprise is incorporated, in a capitalized form, in the promoter's profit. This process has as its premise a relatively high level of development of the banks, and of their connections with industry, and a correspondingly developed market for fictitious capital, the stock exchange" (Hilferding, 1910, Ch. 7).

The importance of the promoter's profit in financial profit accumulation was also perceptively analyzed by two non-Marxist authors: Thorstein Veblen and J.A. Hobson. In his Theory of Business Enterprise (1904), Veblen examined the formation of trusts in the U.S. economy of the early twentieth century and understood very clearly that the objective of mergers and the expansion of credit that accompanied them was to obtain the greatest possible profits, by means of the promoter's profit, as well as superprofits (capital gains) in the stock and bond markets:

Credit operations come into these transactions mainly at two points: in the "financing" of the deal, and in the augmentation of debentures; and at both of these points there is a chance of gain on the one hand to the promoter (organizer) and the credit house which finances the operation, and on the other hand to the stockholders. The gain which accrues to the two former is the more unequivocal, and this seems in some cases to be the dominant incentive to effect the reorganization. The whole operation of reorganization may, therefore, best be taken up from the point of view of the promoter, who is the prime mover in the matter. (Veblen, 1904, Ch. 5) 
Here Veblen distinguishes between two types of financial profit: the main one, the promoter's profit, and another, the stockholder's profit (or capital gains, as it is called now) that are derived from the increase in the value of stocks and bonds involved in the operation.

Business ventures under monopoly-finance capital have nothing in common with the activities of industrial capital in the era before the rise of corporations. In Veblen's view:

The strategic use of credit here involved is, in effect, very different from the old-time use of loan credit in investments. This follows from the peculiar nature of the work which these great captains of industry have in hand, and more remotely, therefore, from the peculiar character of the earnings which induce them to undertake the work. Their work, though it is of the gravest consequence to industry, is not industrial business... Nor is it of the same class as commercial business, or even banking business... It differs also from stock and produce speculation, as that is currently conceived. (Veblen, 1904, Ch. 5)

The value of fictitious capital created by monopoly-finance capital is based on what Veblen called "good-will," that is, on the expectations of profit that a particular operation generates. Capital, he writes, "in the enlightened modern business usage means 'capitalized presumptive earning-capacity,' and in this capitalization is comprised the usufruct of whatever credit extension the given business concern's industrial equipment and good-will will support" (Veblen, 1904, Ch. 5). In a "credit economy," as opposed to a "money economy,"

"capital" means a fund of money values; and since the credit economy and corporation finance have come to be the ruling factors in industrial business, this fund of money values [...] bears but a remote and fluctuating relation to the industrial equipment and the other items which may $[\ldots]$ be included under the old-fashioned concept of industrial capital. (Veblen, 1904, Ch. 6)

In this sense the operations of monopoly-finance capital are a wager based on mere conjectures about the future behavior of the economy. According to Veblen, who agrees here with Keynes, the "putative earning-capacity" associated with "good will":

is the outcome of many surmises with respect to prospective earnings and the like; and these surmises will vary from one man to the next, since they proceed on an imperfect, largely conjectural, knowledge of present earning-capacity and on the still more imperfectly known future course of the goods market and of corporate policy. (Veblen, 1904, Ch. 6) 
If the bet is correct, the financial superprofits of the promoters are assured. If not, the fictional capital created will disappear under the impact of a crisis or will have to be recovered by means of a bailout in which the state acts as lender of last resort - which is to say that the state creates a new fictitious capital in the form of public debt.

For J.A. Hobson - who never developed the concept of financial capital modern finance, as for Hilferding and Veblen, is a result of the emergence and consolidation of the joint-stock company and public debt. One of its principal functions is that of the "promoter." The promoter "will sometimes be himself a great capitalist, or will have intimate business associations with some great banking or finance company which is prepared to 'back' the project by 'underwriting' shares" (Hobson, 1917, p. 239). The main goal of the promoter is maximizing his earnings. The workings of promotion "will be dominated by the desire of the 'vendor' of the project and the 'promoter' to procure for themselves the largest possible proportion of the profits which may accrue, either from the sale of shares to the investing public, or from the development of a steadily remunerative business in case the project is well fitted for a prolonged industrial career" (Ibid., p. 240).

Like Veblen, Hobson considers that the calculation of profit expectations is based on goodwill, which consists of "a just calculation on actuarial and other bases of the future earning-capacity of the business, its capitalisation upon these bases, and the distribution of the stocks and shares and their marketing in forms most convenient to the investing public... An agreed and recognised rate of commission for such work of financial construction and promotion, with a further commission for underwriting, paid either by the vendors or by the Company or both, would be the gain of the promoter and financier" (Ibid., p. 245). Hobson is clear that the purpose of promotion is to provoke an artificial boom in the financial markets and encourage speculation: "The arts of drawing a prospectus and of 'making a market' are devoted to the single end of producing a temporary boom... The motive and effect of these financial arts are to create a false confidence on the part of the ordinary capitalist or investing public which expresses itself in a temporary boom of watered stocks" (Ibid., p. 247).

For Hobson, financiers constitute a "close oligarchy," as the joint-stock company is characterized by a combination of "diffused ownership with concentrated control" (Ibid., p. 240). In the mold of the Marxist theorists of imperialism for whom the emergence of the financial oligarchy represented the creation of a hierarchy within the bourgeoisie, Hobson maintains that small stockholders and investors are a kind of bourgeois proletariat, that they are, in fact, "a great capitalist proletariat, who bear to the operators of finance a relation closely analogous to that which the labouring proletariat bear to the employing class” (Ibid., p. 242). This stratum of the bourgeoisie settles for the crumbs of financial profit.

Traditionally, Marxists who study price formation under the domination of monopoly capital have studied the problem from the perspective of the extraordinary profits made possible by the existence of "entrance barriers" in the productive sector of the economy. That is to say, monopoly profit, which was assumed to be 
greater than average profit, was the result of the transfer of surplus value from less oligopolized companies and economic sectors to more oligopolized ones. But this was a process of "extraordinary profits" taking place at the heart of "real" capital. Financial profit was omitted from the explanation of monopoly prices. This problem needs to be corrected by including the formation of financial profit in the acquisition of monopoly superprofits. Financial profit is made of up promoter's profit, interest, dividends, and superprofits (capital gains) in the financial markets for stocks, bonds, and derivatives. As Hobson notes: "a large proportion of the most profitable business of financiers is never exposed to effective competition, and the prices they receive for their services are 'monopoly' prices" (Ibid., p. 256).

However, if we apply the ideas of Veblen and Hobson to the concept of promoter's profit, the problem of monopoly superprofits acquires another dimension. In this context, I suggest we consider the promoter's profit as an "extraordinary profit," like a monopoly rent, to which only monopoly-finance capital has access, owing to its control over the issuance and circulation of fictitious capital. The form of this monopoly rent more closely resembles the absolute rent used by Marx to explain land rent than the industrial profit of the period of free competition.

Although Hilferding does not explicitly say so, promoter's profit would have to be considered one of the principal mechanisms that counteract the falling rate of profit in monopoly capitalism. The relationship between the emergence of jointstock companies and the factors working against the law of the falling rate of profit had already been brilliantly described by Marx in Volume III of Capital. In Chapter 14 of that volume, Marx analyzes the countervailing tendencies that limit the fall of the rate of profit associated with the increase in the organic composition of capital:

The foregoing five [countervailing tendencies] may still be supplemented by the following... With the progress of capitalist production, which goes hand in hand with accelerated accumulation, a portion of capital is calculated and applied only as interest-bearing capital. Not in the sense in which every capitalist who lends out capital is satisfied with interest, [...] [b]ut in the sense that these capitals, although invested in large productive enterprises, yield only large or small amounts of interest, so-called dividends, after all costs have been deducted... These do not therefore go into levelling the general rate of profit, because they yield a lower than average rate of profit. (Marx, n.d., Ch. 14)

What this means is that when a joint-stock company is formed, and a part of the stockholders are satisfied with a dividend approximating interest rates, another group of capitalists - the financial oligarchy that makes up monopoly-finance capital - can, by means of the promoter's profit and other financial superprofits, appropriate a higher than average rate of profit through the issuance and trading of stocks and bonds. This absorption of extraordinary profits, associated with the control exercised by monopoly-finance capital over fictitious capital, 
through the megabanks and investment banks, additionally allows them to offset the possible lower rate of profit accompanying a crisis. Johnson and Kwak (2011, p. 76) note that during the real estate boom, investment banks obtained extraordinary profits by three means: 1) fees on the securitization of loans; 2 ) fees on the sale of bonds to financial investors; and 3) trading profits on those bonds.

It is worth pointing out here that it is not only the financial intermediaries (commercial banks, investment banks, large institutional investment funds etc.) who participate in the appropriation of the promoter's profit, but also transnational corporations, insurance companies, and rating agencies: that is, the entire network of interests that constitute monopoly-finance capital and that operate on a global scale.

Hyman Minsky was clear about the relationship between securitization and the quest for extraordinary profits on the part of banks and finance capital. In a paper on securitization published near the end of his life, he argued the following:

Securitization also is a response to the cost structure of banks. Banks seem to need a 450-basis-point margin if fund income is to be the source of profits. This provides a great deal of profit space for innovative suppliers with lower costs. Bank participation in securitization is part of the drive, forced by costs, to supplement fund income with fee income. The development of the money market funds, the continued growth of mutual and pension funds, and the emergence of the vast institutional holdings by offshore entities provide a market for the instruments created by securitization... Securitization implies that there is no limit to bank initiative in creating credits for there is no recourse to bank capital, and because the credits do not absorb high-powered money. (Minsky, 2008, p. 3)

\section{CONCLUSIONS}

In this paper I have argued for the advisability of rethinking the Marxist category of finance capital in light of the contributions of Rudolf Hilferding. My central hypothesis is that the fundamental concept developed by Hilferding is neither the process of fusion of bank capital and industrial capital, much less the dominance of banks over industry, but rather the control exercised by monopoly-finance capital over the issuance and circulation of fictitious capital by means of banks, and the relationship of these with securities exchanges and financial markets.

It is necessary not to confuse the category of monopoly-finance capital with the concept of financialization, which has acquired currency since the rise of neoliberalism in the 1980s. Although monopoly-finance capital has been the dominant fraction of the bourgeoisie in the major capitalist countries since the end of the nineteenth century, its domination does not a fortiori imply financialization of economic activity, as the latter depends on the concrete conditions of the reproduction of capital. Building upon the arguments of Braudel and Arrighi that financial- 
izations are processes linked to periods of hegemonic transition, I propose linking the transition to the "finance-dominated accumulation regime" with the crisis in the mode of regulation and the decline in U.S. hegemony that began in the 1970s.

Hilferding demonstrates that the emergence of joint-stock companies modifies the process of creation of average profit and that shareholders are content with receiving a dividend that, although a part of the surplus value generated by production, is approximately the prevailing rate of interest. He proposes the consideration of the promoter's profit as the main source of income of finance capital. Building on the analyses of Hilferding, Hobson, and Veblen of the promoter's profit and other financial superprofits, I propose that these forms of profit are a type of "extraordinary surplus value" that is appropriated by monopoly-finance capital through its control over the issuance and circulation of fictitious capital. In this sense, financial profit has the status of a monopoly rent that resembles absolute land rent, which, according to Marx, depended on the absolute monopoly of the landlord over the land. Under conditions of financialization, monopoly-finance capital increasingly develops into a rentier elite.

Financial profit acts as a countervailing force against the falling rate of profit. If this is true, I would venture the hypothesis that the financialization of the capitalist economy during the past three decades, together with globalization and deregulation, was a reaction and a response by the leading sectors of monopoly-finance capital to counteract the falling rate of profit at the origin of the "great crisis" of the 1970s. Through financialization, monopoly-finance capital succeeded in elevating profit margins, but at the cost of rendering the financial structure more fragile-a process that led to the global crisis we are currently experiencing.

\section{BIBLIOGRAPHY}

Arrighi, Giovanni. (2007). Adam Smith in Beijing. London-New York: Verso. . 2004. The Long Twentieth Century. London-New York: Verso.

Baragar Fletcher and Chernomas Robert. (2012). "Profit Without Accumulation”. International Journal of Political Economy, Vol. 41, No. 3, Fall, M.E. Sharpe, New York.

Baran, Paul and Paul M.Sweezy. (1966). Monopoly Capital: An Essay on the American Economic and Social Order. New York: Monthly Review Press.

Braudel, Fernand. (1992). Civilization and Capitalism, 15th-18th Century. Vol. 3. The Perspective of the World. Berkeley: University of California Press.

Chesnais, Francois. (2000). “Mondialisation, le capital rentier aux commandes.” Les Temps Modernes: 607, January-February.

(1994). La mondialisation du capital. Paris: Syros.

De Brunhoff, Suzanne (1974). La política monetaria. México, Siglo XXI editores.

Duménil Gérard. and Lévy Dominique. (2006). « Les trois champs de la théorie des relations financières de Marx. Le capital financier d'Hilferding et Lénine » in G. Duménil and D. Lévy coord. La Finance capitaliste, Collection Marx Confrontation, Paris

Epstein, Gerald A. (2005). Introduction. In Financialization and the World Economy, ed. Gerald A. Epstein. Cheltenham, U.K.: Edward Elgar Publishing.

Fisher, Irving. 1933. "The Debt-Deflation Theory of Great Depressions." Econometrica, 1(4): 337-357. 
Foster, John B. and Fred Magdoff. (2009). The Great Financial Crisis. New York: Monthly Review Press.

Galbraith, John.Kenneth. (1972). The New Industrial State. New York: New American Library.

Giraud, Pierre-Noel. (2001). Le commerce des promesses. Petit traité sur la finance moderne. Paris: Editions du Seuil.

Guillén, Arturo. (2007). Mito y realidad de la globalización neoliberal. Mexico City: Miguel Ángel Porrúa editores-UAMI. . (1981). Imperialismo y ley del valor. Mexico City: Editorial Nuestro Tiempo.

Hilferding, Rudolf. (1910). Finance Capital. A Study of the Latest Phase of Capitalist Development. Ed. Tom Bottomore. London: Routledge \& Kegan Paul, 1973. Online at http://marxists.org/archive/ hilferding/1910/finkap/ (accessed 17 May 2012).

Hobson, John. (1917). The Evolution of Modern Capitalism. London: Walter Scott Publishing Co.

Johnson, Simon. and James Kwak. (2011). The 13 Bankers. New York: Vintage Books.

Keynes, John Maynard. (1995). Teoría general de la ocupación, el interés y el dinero. Mexico City: Fondo de Cultura Económica.

Krippner, Greta. (2005). “The Financialization of American Economy.” Socio-Economic Review. Online at http://ser.oxfordjournals.org/content/3/2/173.abstract (accessed 16 May 2013).

Lazonick W. and O’Sullivan M. (2010). “Maximizing Shareholder Value: A New Ideology for Corporate Governance". Economy and Society, Volume 29, Issue 1. London.

Lenin, Vladimir I. (1963). Imperialism, the Highest Stage of Capitalism. Online at http://www.marxists. org/archive/lenin/works/1916/imp-hsc/ (accessed 16 May 2013).

Marx, Karl. n.d. Capital, Vol. III. New York: International Publishers. Online at http://www.marxists. org/archive/marx/works/1894-c3 (accessed 17 May 2012).

Minsky, Hyman P. (2008). Securitization. The Levy Economics Institute of Bard College

Policy Note 2008 / 2. Online at: http://www.levyinstitute.org/pubs/pn_08_2.pdf (accessed 16 May 2013).

Palley, Thomas I. (2007). “Financialization: What It Is and Why It Matters.” Political Economy Research Institute, University of Massachusetts, Amherst. Working Paper No. 153. Online at:

http://www.peri.umass.edu/fileadmin/pdf/working_papers/working_papers_151-200/WP153.pdf (accessed 16 May 2013).

Passet, René. (2000). “L'illusion néo-libérale.” Paris: Flammarion.

Pierre, Matari. (2010). «El capital financiero de Hilferding: lecciones y legados para el análisis contemporáneo." Revista Memoria: 246.

Serfati, Claude. (2011). "La logique financiaro-rentière des sociétés transnationales.” European Journal of Economic Systems, 1-2. . (2011). «Transnational Corporations As Financial Groups.» Work Organization, Labour and Globalisation, 5(1).

Sweezy, Paul M. (1994). “The Triumph of Financial Capital,” Monthly Review. Online at: http://www. monthlyreview.org/940600sweezy.php (accessed 17 May 2012).

Sweezy, Paul M. (1942). The Theory of Capitalist Development: Principles of Marxian Political Economy. New York: Oxford University Press.

Sweezy, Paul M. (1983). “Teoría del desarrollo capitalista.” Mexico City: Fondo de Cultura Económica.

Veblen, Thorstein. (1904). The Theory of Business Enterprise. http://socserv2.mcmaster.ca/ econ/ ugcm/3ll3/veblen/busent/index.html (accessed 8 May 2013). 